Summer 2005

\title{
Access to U.S. Federal Courts as a Forum for Human Rights Disputes: Pluralism and the Alien Tort Claims Act
}

Christiana Ochoa

Indiana University Maurer School of Law, cochoa@indiana.edu

Follow this and additional works at: https://www.repository.law.indiana.edu/ijgls

Part of the Courts Commons, Human Rights Law Commons, and the International Law Commons

\section{Recommended Citation}

Ochoa, Christiana (2005) "Access to U.S. Federal Courts as a Forum for Human Rights Disputes: Pluralism and the Alien Tort Claims Act," Indiana Journal of Global Legal Studies: Vol. 12 : Iss. 2 , Article 13.

Available at: https://www.repository.law.indiana.edu/ijgls/vol12/iss2/13

This Symposium is brought to you for free and open access by the Law School Journals at Digital Repository @ Maurer Law. It has been accepted for inclusion in Indiana Journal of Global Legal Studies by an authorized editor of Digital Repository @ Maurer Law. For more information, please contact rvaughan@indiana.edu.

\section{$\Psi$}

JEROME HALL LAW LIBRARY

INDIANA UNIVERSITY

Maurer School of Law
Bloomington 


\title{
Access to U.S. Federal Courts as a Forum for Human Rights Disputes: Pluralism and the Alien Tort Claims Act
}

\author{
Christiana Ochoa
}

\section{INTRODUCTION}

The contribution of this paper to the conference falls under the category of The United States Experience of the Pluralistic Deficit Before the Courts. Rather than discuss the inclusion of U.S. citizens in the judicial process or the U.S. domestic judicial system per se, this paper will address pluralism in the context of the Alien Tort Claims Act (ATCA or the Act) ${ }^{1}$ portion of Sosa v. AlvarezMachain, ${ }^{2}$ which at the time of this conference was being decided by the Supreme Court of the United States. This paper will first briefly describe how the ATCA, and the opposition it has faced, reflects and informs the U.S. position on civic pluralism on an international level, or rather, civic participation by people other than U.S. citizens. Second, the ATCA requires federal courts to incorporate international human rights and humanitarian law into the analysis of cases brought before them on ATCA grounds. ${ }^{3}$ These acts of incorporating law, legal opinions, and jurisprudence from sources other than U.S. state or federal law

*Associate Professor of Law, Indiana University School of Law-Bloomington; J.D., Harvard Law School; B.A., University of Michigan. The author would like to thank the Faculty of Law at the University of Trento for hosting the conference at which this paper was first presented, as well as Dean Robert Toniatti, Fulvio Cortese, Marco Dani, and Francesco Palermo for their invitation to participate therein. In addition, she would like to express sincere gratitude to Timothy Lynch, Alfred Aman, Luisa Antoniolli, Elisabeth Zoller, David Williams, Susan Williams, Luis FuentesRowher, and William Henderson for their insightful comments at various stages of this article's completion. Thanks also to the editors of the Indiana Journal of Global Legal Studies, especially Carmen Brun and Wayne Branom III.

1. The current text of the Alien Tort Claims Act (ATCA or Act) is published as 28 U.S.C. $\S$ 1350 (2005). There have been minor alterations to the statutory language of the ATCA since its original drafting in 1789.

2. Sosa v. Alvarez-Machain was argued on March 30, 2004 and decided on June 29, 2004. See Sosa v. Alvarez-Machain, 124 S. Ct. 2739 (2004).

3. See Alien Tort Claims Act. 
can be framed as acts of legal pluralism. ${ }^{4}$ This paper will therefore propose that courts ought to consider the robust history and tradition of instances of legal pluralism as a means for allowing customary international human rights law to enter our own decisionmaking process and thereby add routes for civic participation available to victims of human rights abuses.

Part I, therefore, will provide a brief historical and contextual background to the ATCA and the litigation that has occurred under it, as well as some of the arguments advanced by those who oppose the Act. Because the decision in Sosa now frames the ongoing debates and litigation in which the ATCA is featured, Part II will summarize the holding in that case. Part III will describe the Act's contributions to increased civic pluralism in order to suggest that the very concept of pluralism-both in terms of civic pluralism and legal pluralism-is at the core of the opposition to the ATCA. Part IV will then propose that, in the case of the ATCA, legal pluralism and civic pluralism are necessarily interconnected. Ultimately, this paper will argue that the increased civic pluralism that the Act provides relies on a willingness to incorporate ideas and methodology from legal pluralism.

\section{History and Context of the Alien Tort Claims Act and Opposition TO THE ACT}

In 1980, the U.S. Court of Appeals for the Second Circuit announced its decision in Filártiga v. Peña-Irala. ${ }^{5}$ The appellants in the case, also the plaintiffs before the trial court, were Paraguayan nationals who sought to convince the Second Circuit that the court had subject matter jurisdiction over a case involving a tort committed in Paraguay by the defendant-appellee who was also a Paraguayan national. ${ }^{6}$ According to the Filártigas, during the time Mr. Peña was the Inspector General of Police in Asunción, Paraguay, Mr. Peña kidnapped, tortured, and killed the Filártigas' son and brother, Joelito Filártiga. ${ }^{7}$ The plaintiffs' alleged violations of "wrongful death statutes; the U.N. Charter; the Universal Declaration on Human Rights; the U.N. Declaration Against Torture;

4. See generally The Role of the Judiciary in Plural Societies (Neelan Tiruchelvam \& Radhika Coomaraswamy eds., 1987) (various authors describing the use of multiple sources of law in the judiciaries of different countries).

5. Filártiga v. Peña-Irala, 630 F.2d 876 (2d Cir. 1980).

6. Id. at 878,880 .

7. Id. at 878 . 
the American Declaration of the Rights and Duties of Man; and other pertinent declarations, documents, and practices constituting the customary international law of human rights and the law of nations." ${ }^{8}$ The plaintiffs relied on these documents as evidence of customary international law prohibiting the treatment to which Joelito Filártiga was subjected. In so doing, they hoped to show that the requirements for liability under the ATCA had been satisfied. ${ }^{9}$ The ATCA provides that "[ $[$ ]he district courts shall have original jurisdiction of any civil action by an alien for a tort only, committed in violation of the law of nations or a treaty of the United States." ${ }^{10}$ The Second Circuit decided in Filartiga that the ATCA "validly creates federal court jurisdiction for suits alleging torts committed anywhere in the world against aliens in violation of the law of nations." 11

Passed by the First Congress in 1789, the ATCA was rarely invoked until the Second Circuit breathed life into it through its decision in Filartiga. ${ }^{12}$ In the nearly twenty-five years since, it has been at the center of a lively controversy over the use of the federal court system as a forum for settling the grievances of foreign nationals. ${ }^{13}$

Over the course of a quarter century, there have emerged what might appear to be three types of cases brought under this statute. The first, of which Filártiga and Kadic v. Karadzic ${ }^{14}$ are the best-known and perhaps the most emblematic, is characterized by foreign plaintiffs bringing suit against foreign defendants. In both cases, the plaintiffs found their defendant in the United States and were able to serve process on that defendant. Their suits included allegations that the defendants, acting under color of law, engaged in tortious violations of international law. These cases involved violations of a select subset of enumerated human rights so grave as to be indisputably prohibited by customary international law and included kidnappings, torture, killings, and violations

\section{Id. at 879 .}

9. Id.

10. Alien Tort Claims Act, 28 U.S.C $\$ 1350$ (2005).

11. Kadic v. Karadzic, 70 F.3d 232, 236 (2d Cir. 1995) (discussing Filártiga, 630 F.2d at 876).

12. Three cases invoked the ATCA prior to Filartiga. See Adra v. Clift, 195 F. Supp. 857, 859 (D. Md. 1961); Moxon v. The Fanny, 17 F. Cas. 942, 947-48 (D. Pa. 1793) (No. 9895); Bolchos v. Darrel, 3 F. Cas. 810,810 (D.C.S.C. 1795) (No. 1607). See also Brief for the United States as Respondent Supporting Petitioner at 17 n. 1, Sosa v. Alvarez-Machain, 124 S. Ct. 2739 (2004) (No. 03-339).

13. The ATCA is central to this debate, particularly as it pertains to accountability for human rights and humanitarian law violations. There are other areas of law cited in this debate, including the long-arm aspects of federal antitrust statutes.

14. Kadic, 70 F.3d at $236-37$. 
of the laws of war. ${ }^{15}$ This type of ATCA case did not require the courts to apply international human rights norms to individuals acting in a private capacity, a practice about which there continues to be significant disagreement and confusion. ${ }^{16}$ Rather, these cases applied international law against state actors or defendants acting under color of state law. ${ }^{17}$ Nonetheless, the opinions published in these cases set the groundwork for cases to be litigated against private actors.

The Karadzic case is probably best thought of as facilitating the transition between the first generation of cases — cases against individuals acting under color of state law - and the second generation, which has involved private actors as defendants. Among the questions in Karadzic was whether Radovan Karadzic was a state actor. ${ }^{18}$ He was the leader of the Bosnian-Serb faction at the time he perpetrated the violations at issue, but this meant he was the leader of an unrecognized government. ${ }^{19}$ According to the district court, this meant he was a private actor, and therefore, could not be held liable for violations of human rights. ${ }^{20}$ The appellate court reversed this decision. It found two separate circumstances under which a private actor could bear international obligations. The first was when the individual commits one of a narrow set of wrongs that are of such gravity that state action is not considered a requisite for responsibility-for example in the case of genocide. The second was when the violations were sufficiently tied to state action as to bring international standards to bear. In Karadzic's case, the court found that the significant support he received from the Yugoslav government tied his acts to the legitimate Yugoslav government, and thereby gave his conduct the color of law. ${ }^{21}$

15. See id.; Filártiga, 630 F.2d at 878.

16. See generally Andrew Clapham, Human Rights In the Private Sphere (1996).

17. The Second Circuit's decision in Kadic v. Karadzic addresses this issue directly. Karadzic was the leader of the "self-proclaimed Bosnian-Serb republic of 'Srpska." See Kadic, 70 F.3d at 236. The court discussed in dicta that the application of certain aspects of international law need not be limited to states or state actors, but preferred to characterize Karadzic as a state actor rather than as a private individual because he was acting under color of law owing to his collaboration with the former Yugoslavia or with substantial Yugoslavian aid. Id. at 245. But see Tel-Oren v. Libyan Arab Republic, 726 F.2d 774, 776 (D.C. Cir. 1984) (Edwards, J. concurring), cert. denied., 470 U.S. 1003 (1985). Judge Edwards stated that the application of international law to private actors is limited in this way: "Specifically, I do not believe the law of nations imposes the same responsibility or liability on non-state actors, such as the PLO, as it does on states and persons acting under color of state law."

18. Kadic, 70 F.3d at $236-37$.

19. Id. at 236 .

20. Id. at 237.

21. Id. at 245 . 
During the era in which ATCA cases were limited to this type of litigationwhen ATCA cases featured state actors committing violations of the most indisputably protected human rights-there was little opposition to the statute. At that time, the U.S. Department of State issued advisory letters to the courts hearing these cases, which encouraged them not only to hear the cases, but to feel at liberty to find the defendants liable for whatever violations they were found to have committed. ${ }^{22}$

Still, the recognition in the Karadzic case that private actors could bear responsibility for human rights violations under the ATCA cleared the path to the second type of ATCA claims and has brought the ATCA international renown. This set of ATCA cases is characterized by foreign plaintiffs' instituting actions against a range of private actors, including corporations of various national origins, for violations of international law based on human rights and environmental claims. The prototypical corporate responsibility cases of this generation are those against large oil and gas multinationals in the extraction business in increasingly remote regions of the world. Famous examples include: a case brought against Royal Dutch/Shell Oil charging the defendants with complicity in human rights violations in Nigeria, particularly the killing of Ken SaroWiwa and others who were protesting a pipeline that was being laid by the company; ${ }^{23}$ the Aguinda $v$. Texaco litigation, in which indigenous people living in a relatively untrammeled region of Ecuador brought an action against Texaco for multiple violations of rights recognized by international human rights treaties; ${ }^{24}$ and a case initiated by Burmese peasants alleging that Unocal was complicit in the violation of various human rights norms, including forced relocation, torture, rape, and murder committed by the Burmese military while providing security for the construction of a Unocal pipeline. ${ }^{25}$

Given the increasing success the second generation of cases has had before federal courts (albeit success on procedural questions), opposition from predict-

22. See Memorandum for the United States Submitted to the Court of Appeals for the Second Circuit, Filártiga v. Peña-Irala, 630 F.2d 876 (2d Cir. 1980) (No. 79-6090), available at http:// www.cja.org/legalResources/FilartigaUSMemo.htm (last visited Apr. 11, 2005); Kadic, 70 F.3d at 51.

23. Wiwa v. Royal Dutch Petroleum Co., 2002 U.S. Dist. LEXIS 3293, at *4_5 (S.D.N.Y. Feb. 22, 2002).

24. Aguinda v. Texaco, Inc., 303 F.3d 470, 473 (2d Cir. 2002).

25. Roe v. Unocal Corp., 70 F. Supp. 2d 1073, 1075 (C.D. Cal. 1999); Doe I v. Unocal Corp., 395 F.3d 932 (9th Cir. 2002). 
able sources has mounted. The National Foreign Trade Council (NFTC) is at the head of this opposition. ${ }^{26}$ They have argued in multiple amicus briefs that the ATCA harms the U.S. economy by placing companies, especially U.S. companies or those with a presence in the United States, at significant risk of being sued by plaintiffs invoking "a bewildering variety of international law rights." This risk and uncertainty, the NFTC argues, creates higher costs in planning, $\mathrm{fi}_{1}$ nancing, and insuring corporate overseas activities. ${ }^{28}$ Companies with a presence in the United States have, in fact, been subjected to liability under the ATCA from which foreign companies have been able to escape owing to a lack of personal jurisdiction over some foreign defendants. ${ }^{29}$ The NFTC argues that the consequences of additional exposure for companies with a U.S. presence are grave for the U.S. economy. ${ }^{30}$

The third type of ATCA cases has only recently started to emerge and is characterized by individuals who act in concert with the U.S. government appearing as its defendants. One such case was Papa v. United States, in which family members of a Brazilian national sued 100 John Does, the U.S. government, and the U.S. Immigration and Naturalization Service (INS) when their husband and father, a Brazilian national, was apprehended by the INS and killed by other detainees while he was in INS custody. ${ }^{31}$ Another example is the case that now frames the continued life and utility of the ATCA: Sosa v. Alvarez-Machain..$^{32}$

This new generation of cases has spawned a new generation of opponents as well. Among them is the executive branch of the U.S. government, often speaking through the State Department that once endorsed litigation under the $\mathrm{ATCA}^{33}$ or, alternatively, through the Justice Department. ${ }^{34}$

26. The National Foreign Trade Council (NFTC) describes itself as "the premier business organization advocating a rules-based world economy." Brief for the NFTC, USA*Engage, the National Association of Manufacturers, the Chamber of Commerce of the United States of America, and the United States Council for International Business as Amici Curiae in Support of Petitioner at 1, Sosa v. Alvarez-Machain, 124 S. Ct. 2739 (2004) (No. 03-339) [hereinafter Brief for NFTC].

27. Id. at 8 .

28. Id. at 12.

29. See, e.g., Roe, 70 F. Supp. $2 \mathrm{~d}$ at 1073.

30. Brief for NFTC, supra note 26 , at $12 \mathrm{n} .18$.

31. Papa v. United States, 281 F.3d 1004, 1008 (9th Cir. 2002).

32. Sosa v. Alvarez-Machain, 124 S. Ct. 2739 (2004). This case is described in greater detail in Part III of this paper.

33. Brief for the United States as Respondent Supporting Petitioner, supra note 12, at 3.

34. The United States has submitted briefs as amicus curiae in a number of cases. See, e.g., id. 
The primary argument being advanced by the executive branch is that the ATCA will have a potentially serious adverse impact in the war against terrorist organizations. The brief for the United States ${ }^{35}$ and the brief filed by Sosa ${ }^{36}$ both argued that, if the Supreme Court were to allow the Ninth Circuit's interpretation of the ATCA, it would not be limited to addressing suits against "rogues and outlaws. ${ }^{37}$ Instead, it would have the capacity to cause governments and individuals that ally themselves with the United States and participate in U.S. antiterrorism, military, and police actions to be brought to trial.

Although the United States is immune from suit under the ATCA, ${ }^{38}$ nations, and individuals, that participate in kidnappings similar to the one at issue in the Sosa litigation, ${ }^{39}$ or the incarcerations at issue in Al Odah v. United States, ${ }^{40}$ can be subject to scrutiny and liability under the ATCA.

Opponents of this set of ATCA claims argue that the Act will hinder the war on terrorism by restricting the types of activities in which U.S. allies will be willing to engage as part of their efforts to assist the war on terrorism, for fear of potentially embarrassing and costly litigation. This will also have the effect of allowing for indirect or vicarious judicial review of the executive branch's efforts to enforce its criminal laws or conduct its military operations, in furtherance of its antiterrorist objectives. If U.S. courts find a foreign government or foreign bounty hunter liable for human rights violations committed while acting in concert with the U.S. government, the fight against terrorism could be hobbled and the U.S. government would face international criticism and embarrassment, even without a finding of culpability directly against the United States.

\section{The Supreme Court's Interpretation of the ATCA in Sosa $v$. Alvarez-Machain: A "Demanding Standard of Definition"}

Humberto Alvarez-Machain, the original plaintiff in the Sosa v. AlvarezMachain litigation, was a Mexican national who was kidnapped in Mexico. His

35. Id. at 17 .

36. Id. at 3 .

37. Id. at 17 .

38. See Al Odah v. United States, 321 F.3d 1134, 1149-50 (D.C. Cir. 2003) (Randolph, J., concurring); see also Brief for the United States as Respondent Supporting Petitioner, supra note 12, at 19.

39. Brief for the United States as Respondent Supporting Petitioner, supra note 12, at 17.

40. Al Odah, 321 F.3d at 1135 (alleging that the military's detention of aliens at the U.S. Naval Base at Guantánamo Bay, Cuba, violates the law of nations and U.S. treaties).

41. Sosa v. Alvarez-Machain, 124 S. Ct. 2769 n.30 (2004). 
abductors were other Mexican citizens acting on behalf of the U.S. Drug Enforcement Administration (DEA). After his abduction, Mr. Alvarez was transported to the United States where he was arrested, imprisoned, tried, and acquitted of involvement in the murder of a DEA agent. After returning to his home country, he sued the Mexican citizens who kidnapped him, including Francisco Sosa, as well as individual DEA agents, the DEA, and the U.S. government for contracting for his abduction. ${ }^{42}$

Following a long history of deliberation in and among the lower federal courts over the content and meaning of the ATCA, the Supreme Court issued its first elaboration on its interpretation of the ATCA in its June 2004 Sosa decision. ${ }^{43}$ While many supporters of the ATCA feared a decision that would eviscerate the ATCA, ${ }^{44}$ the Court's opinion left the door ajar (subject to "vigilant doorkeeping") $)^{45}$ to "independent judicial recognition of actionable international norms" ${ }^{\prime 46}$ such that federal courts may continue to take cognizance of and interpret a "narrow class of international norms." Therefore, the ATCA may serve as a means of redress for those who have suffered violations of that narrow class of norms. ${ }^{47}$ In determining whether a particular norm is of the small set plaintiffs may employ under the ATCA, the Court required that any claim under the law

42. Id. at 2747; Alvarez-Machain v. United States, 331 F.3d 604 (9th Cir. 2003).

43. The Supreme Court had previously accepted cases containing ATCA questions, but did not provide the lower courts with interpretive guidance on the Act in those cases. See Rasul v. Bush, 124 S. Ct. 2686 (2004) (issued just a day before the Sosa decision); Argentine Republic v. Amerada Hess Shipping Corp., 488 U.S. 428 (1989).

44. Among the most readily foreseeable means for nullifying the utility of the ATCA was a strong argument advanced originally by Jack Goldsmith and Eric Posner that the ATCA was a jurisdictional grant only and did not create a private cause of action for violations of customary international law. Significantly, Justice Scalia, in his dissent in Sosa, takes exactly this position. Under this view, unless the legislature has granted a specific cause of action, whether by self-executing treaty or independent legislative action, the ATCA cannot provide the means for redress for violations of norms recognized in international law alone. In the concluding paragraph of his concurrence, Justice Scalia states:

American law-the law made by the people's democratically elected representatives-does not recognize a category of activity that is so universally disapproved by other nations that it is automatically unlawful here, and automatically gives rise to a private action for money damages in federal court. That simple principle is what today's decision should have announced.

Sosa, 124 S.Ct. at 2776 (Scalia, J., concurring).

45. Sosa, 124 S.Ct. at 2764.

46. Id.

47. Id. 
of nations "[1] rest on a norm of international character [2] accepted by the civilized world and [3] defined with a specificity comparable to the features of the 18th-century paradigms" ${ }^{\prime 48}$ recognized by the Court. In other words, federal courts "should not recognize private claims under federal common law for violations of any international law norm with less definite content and acceptance among civilized nations than the historical paradigms familiar when $\S 1350$ was enacted." ${ }^{49}$ While the first two criteria will surely give rise to future ATCA debate and litigation, it is this third requirement, which is likely to give rise to the most active continued deliberation.

In an effort to provide some guidance, the Court provided some limitations on the types of claims that can be entertained by ATCA litigation. Citing to TelOren ${ }^{50}$ and In re Estate of Marcos Human Rights Litigation, ${ }^{51}$ the Court outlines a set of standards for analyzing any given claim. A norm giving rise to liability under the ATCA must be (1) specific or definable, (2) universal, and (3) obligatory. ${ }^{52}$ In addition, the Court sets out a number of other, case-contingent limitations, such as exhaustion of domestic remedies ${ }^{53}$ and case-specific deference to the political branches, especially in cases which may have an impact on U.S. foreign policy. ${ }^{54}$

Significantly, the Court accepted the argument that, as a general matter, the ATCA's jurisdictional grant permits federal courts to recognize a limited set of human rights violations. However, in reviewing the particular facts of Mr. Alvarez-Machain's detention and his assertions that the violations he suffered amounted to violations of customary international law such that the ATCA should grant him relief, the Court applied the above parameters to determine that Mr. Alvarez-Machain's ATCA claims were without merit:

Whatever may be said for the broad principle Alvarez advances, in the present, imperfect world, it expresses an aspiration that exceeds any binding customary rule having the specificity we require.... It

48. Id. at 2761 .

49. Id. at 2765.

50. 726 F.2d 774, 781 (D.C. Cir. 1984) (Edwards J., concurring).

51. 25 F.3d 1467, 1475 (9th Cir. 1994).

52. Sosa, $124 \mathrm{~S}$. Ct. at 2765-66 (citing Tel-Oren, 726 F.2d at 781; In re Estate of Marcos, $25 \mathrm{~F} .3 \mathrm{~d}$ at 1475).

53. Id. at $2766 \mathrm{n} .21$. This principle seems to have guided the Second Circuit's decision in the Texaco litigation, which has been sent back to Ecuador for resolution under the watchful eye of the Second Circuit.

54. Id. 
is enough to hold that a single illegal detention of less than a day, followed by a transfer of custody to lawful authorities and a prompt arraignment, violates no norm of customary international law so well defined as to support the creation of a federal remedy. ${ }^{55}$

For those who were pessimistic about the ATCA's ability to survive the Court's purview in the Sosa case, what is clear from the decision issued is that the ATCA remains a viable statute for foreigners to bring a limited set of claims before U.S. federal courts. While the Supreme Court's decision has limited the scope of viable ATCA claims, litigation under the Act will continue. Debate over acceptable ATCA claims will also continue, and will likely be primarily focused on the exact meaning of specific or definable, universal, and obligatory norms.

\section{The Alien Tort Claims Act as a Tool for Pluralism}

The ATCA serves an essential role in the furtherance of pluralism by allowing for greater civic participation. It does so by at least three means:

- The ATCA helps to alleviate the systemic enforcement deficit from which international law has long suffered.

- The availability of U.S. courts to victims of human rights abuses alleviates the judicial deficit from which individual victims have long suffered.

- The publicity drawn to the violations suffered by plaintiffs under the ATCA alleviates a global information deficit. Such publicity leads to increased global cause-centered involvement, or a diminution of the pluralistic deficit.

This section will discuss each of these means in turn.

\section{A. The ATCA alleviates the systemic enforcement deficit from which international law has long suffered.}

Those working within the human rights system, perhaps more so than within any other aspect of international law, face "wicked problems,"

55. Id. at 2769.

56. The term "wicked problems" and its approach to problem solving is borrowed from Policy Sciences to describe problems, which, among other characteristics, do not have a well-described mmmm 
innumerable and chaotic social, political, economic, and historical circumstances. It has long been recognized that among the most frustrating aspects of the aspirational human rights system are the limited channels through which victims can seek adequate redress for their suffering and, as a corollary, the impunity with which violators can infringe on human rights. ${ }^{57}$

Several forums exist to hear human rights claims, ranging from those available through the United Nations, to the regional systems for human rights, and to the newly established International Criminal Court. Still, the number of human rights abuses committed each day relative to the small number of abuses these bodies are able to accept and handle is evidence of the lack of sufficient legal channels to hear these claims. One current example is the flood of human rights communications received by the United Nations Human Rights Committee. ${ }^{58}$ There are now such high numbers of communications received from victims that the Committee simply cannot address them all. This is a systemic problem inherent in the current human rights framework.

Even if the Committee were able to address all the communications it receives under the current committee protocols, a given victim would never receive more satisfactory redress than the diplomatically phrased admonitions made by the Committee against human rights violators. Like many of the human rights bodies, it has no ability to enter a judgment against a violator or grant compensation to victims. This is surely a desirable characteristic under some circumstances. But it is not ideal in all circumstances. The regional systems for human rights protections are similarly overloaded, and while they are able to grant compensation, they are not able to do so expeditiously.

By providing access to domestic courts, the ATCA provides a new channel for the resolution of a limited class of human rights disputes. In 1992, Belgium en-

set of potential solutions. Wicked problems are those for which solutions are very difficult to recognize. A characteristic of a wicked problem is that in solving a wicked problem, the solution of one aspect may reveal another, more complex problem. See generally Horst W.J. Rittel \& Melvin M. Webber, Dilemmas in a General Theory of Planning, 4 PoL'Y Scr. 155 (1973) (describing how current scientific problem solving solutions cannot deal with social policy "wicked problems") [hereinafter Dilemmas in a General Theory of Planning]. See also Horst W.J. Rittel \& Melvin M. Webber, Planning Problems are Wicked Problems, in Developments in Design Methodology 135 (Nigel Cross ed., 1984) [hereinafter Planning Problems are Wicked Problems].

57. Henry J. Steiner \& Phillip Alston, International Human Rights in Context: Law, Politics, Morals 592-983 (2d ed. 2000) (discussing enforcement of human rights).

58. Ivan Shearer, Member of United Nations Human Rights Committee, Lecture to Human Rights Seminar, Indiana University School of Law-Bloomington (Mar. 2004). 
acted a similar law (which has since been repealed), ${ }^{59}$ granting universal jurisdiction to Belgian courts in cases involving criminal violations of humanitarian law. ${ }^{60}$

59. Human Rights Watch, Human Rights News: Belgium: Universal Jurisdiction Law Repealed, at www.hrw.org/press/2003/08/belgium080103.htm (last visited Apr. 15, 2005).

60. In May 2003, a lawsuit was filed in Belgium under its humanitarian law against U.S. Army General Tommy Franks for violations of the Geneva Conventions. Richard Bernstein, Belgium: War Crimes Complaint Against Franks, N.Y. Times, May 15, 2003, at A12. Cases were also filed against former President George W. Bush, Dick Cheney, and then-Generals Colin Powell and Norman Schwarzkopf "for alleged crimes in the first Gulf War." Robert H. Bork, WALL ST. J., June 22, 2003 (online editorial). The ATCA bears similarities to universal jurisdiction statutes in that the primary objective is to ensure that grave violations of human rights do not go unaddressed and ensuring that their perpetrators do not enjoy impunity. It is also similar in the types of avenues the ATCA and universal jurisdiction statutes provide for civic pluralism. The demands they make on domestic court systems to include international law as part of the domestic legal system-increasing legal pluralism-are also similar. However, there are important differences.

The universal jurisdiction statutes are modern statutes. For example, the Belgian Statute was passed in 1993, amended in 1999 and again in 2003, before being repealed in June 2003. As such, modern universal jurisdiction statutes are very specific about the international law provisions they address. The Belgian statute specifically referred to or incorporated the 1949 Geneva Conventions on war crimes, and their protocols, the Genocide Convention and crimes against humanity, largely as defined by the Statute of the International Criminal Court. The provisions of international law which are included in these statutes are undeniably the human rights and humanitarian law provisions about which there is no dispute. They are obligations under treaty law and have also risen to the status of customary international law and even the small subset of customary law from which there can be no derogation by individual states - they have the status of $j u s$ cogens.

The language of the ATCA is not so specific or discriminating. It was promulgated in 1789 and simply is not drafted with the same particularity as modern statutes. The Second Circuit decided in Filartiga that the ATCA "validly creates federal court jurisdiction for suits alleging torts committed anywhere in the world against aliens in violation of the law of nations." Kadic $\mathrm{v}$. Karadzic, 70 F.3d 232, 236 (2d Cir. 1995) (discussing Filártiga v. Peña-Irala, 630 F.2d 876 (2d Cir. 1980)). This was the extent of its specificity when it was revived by the Second Circuit.

The ATCA is also distinct from universal jurisdiction statutes in that universal jurisdiction statutes are criminal statutes, providing for imprisonment for periods from 10 years to life, or given the emphasis on the gravity of these crimes and the need to punish them, universal jurisdiction statutes often state that the highest penalty available should be applied. The consequences on the life and liberty of the defendants, in other words, can be quite grave under universal jurisdiction statutes. In addition to the criminal aspects of universal jurisdiction statutes, defendants may face civil liabilities as well. As the name of the Alien Tort Claims Act indicates, however, defendants face only civil liabilities in the form of monetary consequences, not criminal sanctions. 
Spain has also enacted a universal jurisdiction criminal statute. ${ }^{61}$ By means of hearing cases brought under such statutes, a limited number of domestic courts have become legitimate, established, and respected locations for the resolution of some human rights disputes, alleviating one of the most vexing systemic deficits in international law-the lack of mechanisms for the enforcement of human rights violations.

Wicked problems require multiple open routes for solutions. ${ }^{62}$ By their nature, these problems are complex and are not easily resolved by one or two available mechanisms. ${ }^{63}$ An exhortation that human rights are fundamental to being human is powerful. But without adequate means for redress, violations of basic human rights may lead to widespread discontent, widespread malaise, or violent solution-seeking. In order to minimize impunity and the attendant popular disenfranchisement it creates, the greatest number of viable routes for legitimately and equitably resolving human rights violations ought to be made available.

B. The availability of U.S. courts to victims of human rights abuses alleviates the judicial deficit from which individual victims have long suffered.

Some individuals, who have long been powerless to assert their human rights and seek redress for violations thereof, are currently able to use U.S. federal courts as a forum for the airing and resolving of a class of human rights disputes. What does this mean in practical terms? The Filártiga family, the first to be awarded a judgment under the ATCA, was awarded a handsome sum as compensation for the torture and killing of their father and brother.$^{64}$ The victims in a multitude of other ATCA cases have also been granted declaratory and monetary relief. ${ }^{65}$ For those who are victims of violations of a small subset of well-defined, customary human rights norms, redress and compensation are available.

61. See Siro Francisco García Pérez \& Fco. Javier Gómez de Liaño Botella, Ley Orgánica del Poder Judicial: Documentación Legislativa y Jurisprudencial, Comentarios (1985) (setting forth the terms of Article 23(4) of Spain's Organic Law of the Judicial Power); Ley orgánica, $6 / 1985$, de 1 de julio, art. 23.4 (a), (b) (Sp.) (permitting criminal jurisdiction even if an offense was committed outside of Spain, if committed by a foreigner).

62. See Dilemmas in a General Theory of Planning, supra note 56, at 160-67; Planning Problems are Wicked Problems, supra note 56, at 135-44.

63. See id.

64. See Filártiga, 630 F.2d at 876 . It should be noted, however, that although the Filártigas were awarded a $\$ 10$ million judgment, no payment was ever made under the judgment.

65. See, e.g., Kadic, 70 F.3d at 232. 
In all too many instances, domestic courts in the locations where violations take place are either inadequate to handle the actions brought by victims, are unwilling to sustain cases they believe will have negative economic consequences for the country, or are not seen as legitimate by their populations. For example:

Ecuador's judicial system does not even recognize the concept of a class-action lawsuit and has no history of environmental litigation whatsoever. (The system is also notoriously corrupt; a poll by George Washington University found that only 16 percent of Ecuadoreans have confidence in their judiciary, lower than in any other Latin American country except Guatemala. ${ }^{66}$

By providing a location for suits alleging human rights violations by means of the ATCA, the United States offers itself as a legitimate and well-established judicial system —one that is respected globally for its fairness and efficiency-to some of the world's least protected people. The conditions leading to their becoming victims, including being poor or under-protected within their own domestic systems, are mitigated when they are given access to protection and compensation for violations they may experience. In this way, one of the deficits from which they suffer, access to judicial means of dispute resolution, is alleviated.

This type of individualized judicial empowerment is an alternative to violence resulting from disenfranchisement. It is perhaps because of avenues available to those who suffer human rights violations that gatherings such as the January 2004 meeting of the World Social Forum (WSF) in Mumbai, at which over 100,000 people from all over the world gathered to discuss anticapitalist sentiments, can occur and can conclude without incitements to violence. ${ }^{67}$ Indeed, this meeting was imbued with hope and empowerment, such that the slogan of the WSF reads "Another World is Possible."68 Given their numerical strength, coupled with their "opposition to a process of globalisation commanded by the large multinational corporations and by the governments and international institutions at the service of those corporations' interests, with the complicity of na-

66. Eyal Press, Texaco on Trial, The Nation, Mar. 31, 1999, at 11-12, available at http://www. thenation.com/doc.mhtml $\mathrm{i}=19990531$ \&s = press (last visited Feb. 11, 2005).

67. Immanuel Wallerstein, A Rising New Force in World Public Opinion, Yale Global Online, Jan. 28, 2004, at http://yaleglobal.yale.edu/display.article? id=3211 (last visited Mar. 30, 2005).

68. See World Social Forum, at http://www.wsfindia.org (last visited Mar. 30, 2005). 
tional governments, ${ }^{\prime 69}$ it seems imperative that there be avenues of hope for the populations with whom such activists are concerned.

The ATCA has been in its current state of active play for only a quarter century. It is thus not hard to envision the world without it. In no way does this article suggest that the future of the human rights movement depends upon the continued availability of the ATCA. However, it is certain that the more routes available for addressing human rights violations committed against traditionally under-protected people, the more likely they are to feel themselves a part of their own communities and the global community as well. The ATCA is important as one such avenue for those seeking a secure home for human rights claims. It has gained renown as an important tool for increasing access to and participation in the judicial system. In this way, the U.S. federal courts have become intrinsically connected to alleviating a deficit in global judicial and civic pluralism.

\section{The publicity drawn to the violations suffered by plaintiffs under the ATCA} alleviates a global information deficit. Such publicity leads to increased global causecentered involvement, or a diminution of the civic pluralism deficit.

Some commentators have asserted that "the principal benefit of the Alien Tort suits for plaintiffs may be the publicity they can generate." ${ }^{70}$ The use of publicity to generate sympathy for human rights victims and ire against violators has been seen by human rights advocates as an essential part of their work. The centrality of public awareness campaigns to the protection of human rights has only continued to increase with time. Human Rights Watch and Amnesty International, among the two best-known and long-established nongovernmental organizations working on these issues, have persistently used the news media as a crucial means to advance human rights and raise awareness of abuses in all regions of the world.

In the United States, court cases, especially against the rich and powerful, have long been newsworthy and a source of intrigue for the general population. In this atmosphere, cases levied against especially the first and second type of ATCA defendants described herein (foreign officials and transnational corpora-

69. See World Social Forum, Charter of Principles, at http://www.wsfindia.org/charter.php (last visited Mar. 30, 2005).

70. Anne-Marie Slaughter \& David Bosco, Alternative Justice: Facilitated by Little-Known 18thCentury Law, Crimes of War Magazine: The Tribunals, May 2001, at http:/crimesofwar.org/ tribun-mag/mag_relate_alternative.html (last visited Mar. 30, 2005). 
tions) have often drawn widespread media attention. ${ }^{71}$ The stories covering these suits address the particular harms alleged by the plaintiffs, but they also disclose the conditions under which the abuses took place. ATCA

lawsuits are likely to have more of a deterrent impact... given that the lawsuits receive more publicity in the defendants' home countries, in part because the defendants in the civil suits tend to be high level offenders and because the civil trials are open to the public. $^{72}$

Social, labor, and environmental movements around the world have been bolstered by the evidence disclosed in ATCA cases of human rights abuses by corporate entities or corporate complicity in human rights abuses committed by governments and/or private and public security forces acting on their behalf. The astounding and still growing number of participants involved in the antiglobalization demonstrations in Seattle, Washington, D.C., Brazil, and Mumbai, in part, has been educated about the human rights abuses attendant with current forms of globalization through the publicity generated by court cases brought against corporate defendants under the ATCA. The litigation against foreign officials such as Ferdinand Marcos, the former Philippine president, Radovan Karadzic, the Bosnian-Serb leader, and others have also received widespread media attention.

The significance of this media attention must not be underestimated. It is one of the more powerful "original" and "informal" methods ${ }^{73}$ used in recent years to try to influence decisionmaking in such a way that environmental, labor, and human rights are more central to decisionmaking at all levels of political life, including within the political and judicial branches of government. ${ }^{74}$

71. See Brief for NFTC, supra note 26 , at 4, 26-27.

72. Id. at 26-27.

73. This phrase is borrowed from the Presentation Statement of this conference. See Back to Government? The Pluralistic Deficit in Decisionmaking Processes and Before the Courts, Presentation Statement (June 11,2004), reprinted in Fulvio Cortese et al., Back to Government? The Pluralistic Deficit in the Decisionmaking Processes and Before the Courts, 12 Ind. J. Global Legal Stud. 409,410 (2005).

74. See Wallerstein, supra note 67. 


\section{Part IV. The Current Interpretation of the Alien Tort Claims Act Requires the Courts to Consider Legal Pluralism}

Litigation under the ATCA can make valuable contributions to alleviating the pluralistic deficits present when human rights victims are not otherwise recognized, protected, or compensated. The battle, however, over whether it will be able to serve this deficit relief function may ultimately depend on the Court's position on ideas of legal pluralism.

Legal pluralism theory has long engaged in identifying and analyzing situations in which more than one source contributes to the legal rules, norms, or laws at play in a particular issue, society, or situation. ${ }^{75}$ Often the dialogue around legal pluralism takes place in the context of legal anthropology or through the elaboration by legal scholars of the common-law systems alive and at work within countries that are in the process of developing a strong state, legislative process, and judicial functions ${ }^{76}$ as they are keenly aware of the interplay of ancient, common, or customary legal systems with the state power-based legal regimes that are being created in a given location.

Much less common are clear articulations of the daily interplay of various sources of rules, norms, and/or laws in long-established, state power-based legal systems, which rely on the legal centrist belief that only the state has the power to create and enforce law. ${ }^{77}$ This is not to say that such interplay is nonexistent, but that it has not been commonly identified, labeled, and discussed in these terms.

Opponents of the ATCA asked the Court to rule that the Act is a jurisdictional provision only and does not create causes of action. As described earlier in this

75. See generally, Gordon R. Woodman, Ideological Combat and Social Observation: Recent Debate About Legal Pluralism, 42 J. Legal Pluralism 21 (1998) (briefly describing the emergence of legal pluralism and its ongoing debates).

76. See generally Dolores A. Donovan \& Getachew Assefa, Homicide in Ethiopia: Human Rights, Federalism, and Legal Pluralism, 51 AM. J. Coмp. L. 505 (2003) (giving an anthropological description of the development of an Ethiopian government that incorporates a variety of ethic customary law systems while at the same time maintaining acceptable standards of protection for human rights).

77. See generally Woodman, supra note 75. For the most part, this scholarship focuses on newly emerging legal systems or those that are widely acknowledged as developing or in a state of flux. See, e.g., Mireille Delmas-Marty, Towards a Truly Common Law: Europe as a Laboratory for Legal Pluralism (Naomi Norberg trans., 2002) (1994) (describing European reconfiguration and pluralism as crucial elements to developing a new common law system that is focused on the primacy of human rights). 
paper, such a ruling would likely have rendered the Act useless for human rights cases by limiting its application to situations that virtually do not exist-those in which human rights victims are able to find and apply U.S. statutes or to find and apply human rights treaties that the United States has ratified and made selfexecuting such that they grant individuals private causes of action under them.

By using this process-grounded argument, the briefs supporting Sosa's case argued vigorously that the only legitimate law for courts to consider under the ATCA is specifically congressionally adopted law. ${ }^{78}$ In so doing, they attempted to limit the substantive provisions of international law's human rights provisions, whether derived from custom or treaty, from entering into the accepted jurisprudence of the nation's highest court. They advance this argument despite the uniformly hospitable treatment the lower courts have given human rights provisions found in the law of nations or in the treaties to which the United States is a signatory. ${ }^{79}$ If successful, this attempt to interpret the ATCA as nothing more than a jurisdictional grant would have had the effect of limiting legal pluralism by labeling customary international law as an illegitimate source of law for federal courts to apply and restricting the sources to which they can legitimately look to U.S. statutory law alone.

While deciding that the Act is a jurisdictional grant only, the Court also stated that this jurisdictional grant permits federal courts to recognize a limited set of customary international law norms. ${ }^{80}$ In other words, for at least a very limited set of circumstances, courts need to consider the proper application and content of customary international law in order to render decisions on ATCA claims. The requirement that federal courts look to the international legal system, and the mandate to do so, will require a strong understanding of the history and process undertaken in other instances of legal pluralism.

\section{Conclusion}

In limited terms, the Sosa litigation before the Supreme Court challenged "only the legal authority of low-level DEA agents to hire bounty hunters...to abduct" a foreign national over the protests of his government. ${ }^{81}$ In deciding this

78. See, e.g., Brief for the United States as Respondent Supporting Petitioner, supra note 12, at 24-46.

79. Brief for the Respondent at 8, Sosa v. Alvarez-Machain, 124 S. Ct. 2739 (2004) (No. 03-339).

80. Sosa v. Alvarez-Machain, 124 S. Ct. 2739, 2754 (2004).

81. Brief for the Respondent, supra note 79, at 6. 
case, the Court simultaneously navigated the issues of civic participation and legal pluralism discussed herein.

This decision will have significant effects. First, opportunities for greater civic engagement and pluralistic participation on behalf of some of the world's least recognized and least included populations have been preserved, at least in limited circumstances.

As previously explained, a decision to limit the ATCA would likely have had the simultaneous effect of limiting the publicity received by the human rights violations currently addressed by the ATCA. Widespread informed political participation on the part of people socially and geographically far removed from the actual victims of abuses, but who may sympathize, organize, vote, or otherwise engage in civic activities in an effort to ensure that human rights victims are provided with avenues to seek justice, depends upon the reporting of human rights conditions and violations. When violations are widely publicized, more people become aware of human rights and engage in their protection. This is the case both within government and outside of it, whether through political activism or more private means. Limiting publicity, therefore, diminishes political participation among a greater population. The Court's decision in Sosa maintains the possibility of widespread publicity for violations that are brought to the attention of U.S. courts under the ATCA.

A decision that the ATCA is a jurisdictional grant alone would have removed one locale inhabited by legal pluralism since the 1980 Filártiga decision. Litigation under the ATCA has created a space where federal courts actively engage U.S. domestic law, the treaty law of the United States, and customary international law, as well as the jus cogens subset of customary international law. This is by no means the only place where the U.S. courts have entertained international law in making their decisions and it is certainly not the only space within the U.S. judicial system where legal pluralism is at play. It is, however, a notable location of legal pluralism because, if the Supreme Court is willing to accept the challenges and complexities legal pluralism entails within the context of the ATCA, the federal courts can make their contribution to one of the most wicked of problems faced by international law: the enforceability of human rights.

What this means in practical terms is two-sided. While it certainly means that individual plaintiffs under the ATCA can hope for redress, it also means that the violators, whether they are government officials, multinational corporations, or bounty hunters, are on notice that the human rights obligations agreed to by the community of nations are real. It means human rights can be enforceable, and it 
means they must be respected together with domestic laws. If enforcement and punishment are essential ingredients to deterring unwanted behavior, the ATCA provides an opportunity for stemming future human rights violations.

Just as the effect of this enforcement is two-sided, so is what it means for increased civic pluralism. On the one hand, it increases the civic engagement that individual, traditionally unrepresented people have with government through the litigation of these claims in U.S. federal courts. It also forces violators to engage with the government by reeling them in and communicating that they are not outside of, or beyond, the scope of the law. They are and will be engaged if they violate human rights, regardless of where they commit the violations and regardless of the nationality of their victims.

Allowing foreigners to access and use U.S. courts through the ATCA may have the effect, in many instances, of providing a sort of representation on the international plane that is all too often not afforded to individual victims of human rights abuses. While this sort of expost facto representation is preferred to no representation at all, it is problematic. From the perspective of victims, it is much more difficult to know of let alone use judicial resources that will provide them adequate remedies if these paths are not clearly defined ahead of time. Also, from the perspective of perpetrators, for example the corporate entities that have actively lobbied against the ATCA and universal jurisdiction statutes, using the courts as the location for participation and civic pluralism has the effect of creating instability and unpredictability that might not exist if there was early engagement with the communities advancing the human rights interest. Early engagement, at the rulemaking stage rather than the adjudicatory stage, might lead to clear rules to which current or potential violators can adhere in order to avoid litigation of this sort. The ATCA, seen in this way, is a last-ditch effort at justice. Yet, such an effort is still worth while. It is precisely its character as a tool of last resort that makes its continued viability imperative. 